\title{
FEATURES OF THE APPLICATION OF THE DECISIONS OF THE EUROPEAN Court of Human Rights by UKRainian Courts in TAX CASES
}

\author{
Igor Babin $^{1}$
}

\begin{abstract}
The purpose of this article is to explore the subject of applying to the European Court of Human Rights in tax cases, the place of decisions of the European Court of Human Rights in the system of sources of tax law, the problems arising from the application of ECtHR decisions by Ukrainian courts in tax cases. The research was carried out using formal-dogmatic, system-structural, comparative-legal, historical and other methods of scientific cognition. The author concludes that it is important to use the decisions of the European Court of Human Rights to resolve public law disputes, the subject of which is public finances. After all, the Ukrainian tax system and tax legislation, the tax status of taxpayers and tax authorities should be based on the fundamental principles enshrined in the Convention and which have repeatedly been systematically interpreted in the decisions of the European Court of Human Rights.
\end{abstract}

\section{Keywords}

European Court of Human Rights, Tax Law, Case Law, Ukraine

\section{Introduction}

On July 17, 1997, the Verkhovna Rada of Ukraine ratified the Convention for the Protection of Human Rights and Fundamental Freedoms of 1950, which entered into force for Ukraine on September 11, 1997. From that moment on, the role of the European Convention and the case law of the European Court of Human Rights in the legal system of Ukraine begin to actively attract the attention of researchers, both individual publications and complex dissertation works are devoted to it. This problem is the focus of modern state policy, including in connection with the reform of the judicial and law enforcement system, the legal education system, and is a priority area of support from leading international organizations and their branches in Ukraine - the Council of Europe Office in Ukraine, OSCE Project Coordinator in Ukraine and others. At the state level, the Government

\footnotetext{
${ }^{1}$ Yuriy Fedkovych Chernivtsi National University, Kotsjubynskyi St. 2, Chernivtsi, 58012, Ukraine. E-mail:
} i.babin@chnu.edu.ua. 
Ombudsman of the European Court of Human Rights directly addresses this issue. The Ministry of Justice, through the Government Ombudsman of the European Court of Human Rights, representing Ukraine in the European Court of Human Rights when considering its compliance with the Convention for the Protection of Human Rights and Fundamental Freedoms and reporting on the implementation of the decisions of the European Court of Human Rights in cases against Ukraine.

However, the decisive role of the European Convention and the case law of the Court in the national legal system is due not only to the binding force of decisions of the Court in cases against Ukraine, but also to the legally recognized possibility of applying the case law of the European Court of Human Rights by the courts of all jurisdictions in the administration of justice.

The Convention for the Protection of Human Rights and Fundamental Freedoms does not provide for special rights or freedoms for taxpayers. However, the payer, as the subject of the tax relationship, enjoys the protection provided by the Convention. Theorists and practitioners, including judges of the European Court of Human Rights, as a new dimension of the Convention, now consider the protection of the right to peaceful enjoyment of property provided for in Article 1 of Protocol No. 1. The purpose of this article is to explore the subject of applying to the European Court of Human Rights in tax cases, the place of decisions of the European Court of Human Rights in the system of sources of tax law, the problems arising from the application of ECtHR decisions by Ukrainian courts in tax cases. The use of European Court of Human Rights decisions by Ukrainian courts in the future may have a positive impact on the quality of tax litigation. After all, the domestic tax system and tax legislation, the tax status of taxpayers and tax authorities should be based on the fundamental principles enshrined in the Convention and which have repeatedly been systematically interpreted in the decisions of the European Court of Human Rights.

\section{Tax disputes as the subject of consideration by the European Court of Human Rights}

Although the European Court of Human Rights in case of Ferrazzini v. Italy, July 12, 2001, appl. No. 44759/98 found that tax disputes as such were not covered by the protection provided for in Article 6 of the Convention for the Protection of Human Rights and Fundamental Freedoms (right to a fair trial), however, this rule did not apply to cases of breach of tax or other financial legislation, in particular in cases where the person is ordered to pay fines or the property and funds are recovered indisputably. Also interesting in this context is the case of Von Sydow v. Sweden, 08.10.1987, appl. No. 11464/85, where even the obligation of a private person to pay tax at the maximum rate was regarded by the Court as a criminal charge. Overall, analyzing the case law of the Court, we can conclude that, since tax penalties apply to a sufficiently large number of persons, they are consistent with the nature of Article 6 criminal charges. On the other hand, in order to satisfy the criterion of the form and gravity of the legal consequences for the addressee, the measure of liability, which implies a fine, must play the role of a threat that would prevent the re-offending. This doctrine is very well reflected in the decision in case of 
Jussila v. Finland, 23.11.2006, appl. No. 73053/01. The point is that in deciding whether to apply Article 6 of the Convention for the Protection of Human Rights and Fundamental Freedoms to specific legal relations which are relevant to the area of procedural law and which involve the bringing of a person to legal liability, it is for the Court to decide whether there are grounds to equate the relations of the parties with those formed during the administration of justice in criminal cases. It should also be borne in mind that a large part of the European Court of Human Rights' decisions in tax cases were taken precisely as a result of the consideration of decisions of national courts in criminal cases. For example, the decision in cases of Merit v. Ukraine, March 30, 2004, appl. No. 66561/01, Kurt Nielsen v. Denmark, 02.15.2000, appl. No. 33488/96, Mooren v. Germany (GC), 09.07.2009, appl. No. 11364/03 and others. As a whole, the subject matter of an appeal to the European Court of Human Rights of applicants in cases relating to taxation is:

* violation of the right to a fair trial: the tax administration's decision on tax penalties was enforced before the court ruled on the obligation to pay such penalties (Janosevic v. Sweden, 23.07.2002, appl. No. $34619 / 97$ and Västberga Taxi Aktiebolag and Vulic v. Sweden, 23.07.2002, appl. No. 36985/97);

* the tax amount has been deducted without proper litigation (Jussila v. Finland, 23.11.2006, appl. No. 73053/01);

* violation of a person's right of access to a court (Matsyuk v. Ukraine, 10.12.2009, appl. No. 1751/03), and $\S 1$ and $\S \S 3$. b-d $\S 3$ Art. 6 of the Convention concerning the consideration of a case by an impartial tribunal as a result of the dissemination by the central body of the MRF information of the complainant's criminal activity (Feldman v. Ukraine, 08.04.2010, appl. No. 76556/01 and 38779/04);

* delaying the tax authorities with judicial review of the case: Kadri v. France, 27.03.2001, appl. No. 41715/98) - the proceedings took about 12 years; Smirnov v. Ukraine, 30.07.2009, appl. No. 1409/03 and Sokor v. Ukraine, 09.12.2010, appl. No. 49009/07 - the district court proceedings on the legality of actions of tax authorities were suspended for about three years;

* no returns of the tax overpayment within the time limits set by law (Rakitin v. Ukraine, 11.01.2007, appl. No. 7675/04);

* compensation to physical persons of damage caused by unlawful actions or inaction of officials of the MRF body in the exercise of their powers (Terem LTD, Chechetkin and Olius v. Ukraine, 18.10.2005, appl. No. 70297/01 and Vergelskiy v. Ukraine, 12.03.2009, appl. No. 19312/06);

* the obligation of the payer to provide documents that could be grounds for holding him liable for violation of tax law (J. B. v. Switzerland, 03.05.2001, appl. No. 31827/96);

* discrimination in the provision of benefits in taxation, i.e. violation of Art. 14 of the Convention in conjunction with Art. 1 of Protocol No. 1 to it (Burden v. The United Kingdom, 29.04.2008, appl. No. 13378/05);

* violation of the applicant's property rights as regards the non-compliance by the national authorities with the requirements of the legislation regarding the approach 
most favourable to the applicant - the taxpayer, in case of ambiguous interpretation of the national legislation (violation of Article 1 of Protocol No. 1 to the Convention in case of Shchokin v. Ukraine, 14.10.2010, appl. No. 23759/03 and 37943/06);

* reduction of the tax rate in accordance with the normative act applied to these relations (Ferrazzini v. Italy, 12.07.2001, appl. No. 44759/98) and others.

According to Vaško (2019), "the ECHR respects national law and national courts in assessing the issues of admissibility of evidence, assessment of national courts in relation to the strength of the evidence, its relevance, the veracity and the evidential value. However, the ECHR reserves the right to examine whether the act considered in its entirety, including the execution of evidence for the benefit or disadvantage of the accused, was of a fair nature within the meaning of the Article 6 of the Convention".

Certainly, numerous decisions of the European Court of Human Rights on the application of Article 6 of the Convention for the Protection of Human Rights and Fundamental Freedoms and Article 1 of the First Protocol thereto, revealing the multifaceted content of the "right to a fair trial" and "the right to peaceful enjoyment of property" are subject to the study, analysis and practical implementation when considering tax disputes. First of all it concerns such aspects of the "right to a fair trial" as "the right of access to justice", "the right to hear cases within a reasonable time", "the right to a reasoned judgment", "the right to request examination of witnesses" and so on.

In its decisions concerning the violations of Article 1 of Protocol No. 1 to the Convention for the Protection of Human Rights and Fundamental Freedoms, the European Court of Human Rights has developed approaches to the practical understanding of such crucial legal categories as "the principle of proportionality and the balance of interests", "the principle of effective and dynamic interpretation", "principle of quality and predictability of law", "principle of ensuring legal certainty", "principle of ensuring a certain freedom of national discretion", "the principle of autonomous interpretation", "the principle of taking into account generally recognized international standards and principles of international law", "the principle of ensuring minimum guarantees of human rights and freedoms"

\section{Decision of the European Court of Human Rights in the system of sources of tax law of Ukraine}

The sources of any branch of law are an external expression of the legal rules and principles based on which legal relations arise, change and terminate. The effective application of such rules is determined by the place of the source of the law in which they are contained in the system of law. Accordingly, if the place of such a source of law is not yet fully understood, the implementation of the rules contained therein is doomed to encounter difficulties in practice. In accordance with the provisions enshrined in Article 9 of the Constitution of Ukraine and the Law of Ukraine "On International Treaties of Ukraine", current international treaties, consent to the mandatory action of which was granted on the territory of Ukraine by the Verkhovna Rada of Ukraine, are part of the national

\footnotetext{
${ }^{2}$ Mazur, Tahiiev, Benitskyi, Kostrytskyi (2006).
} 
legislation. Thus, after its ratification, the Convention for the Protection of Human Rights and Fundamental Freedoms became a constituent part of national law and a source of law, but no longer European but national. It should be fully implemented by state bodies of Ukraine as an act of domestic law, including tax legislation.

In turn, the issue of the place of the decisions of the European Court of Human Rights in the system of sources of law is the subject of an ongoing debate, which is still pending. Sadchykova (2009) identifies two approaches to addressing this problem: "through a general theoretical definition of the concept of 'source of law' and through the interpretation of the provisions of the laws of the States that have acceded to the Convention through its ratification". The first approach is to deny recognition as a source of law the decisions of the European Court of Human Rights. This traditional approach is based on the principle of rigid distribution of state power, since in this case judicial lawmaking would conflict with the legislative activity of parliament. According to the second approach, having acceded to the Convention for the Protection of Human Rights and Fundamental Freedoms in 1950, the state recognizes the jurisdiction of the European Court of Human Rights for the interpretation of the Convention and its Protocols, surrenders part of its sovereignty, and undertakes to bring its domestic legislation in line with European standards.

In accordance with Article 1 of the Law of Ukraine "On Ratification of the Convention for the Protection of Human Rights and Fundamental Freedoms of 1950, the First Protocol and Protocols No 2, 4, 7 and 11 to the Convention", Ukraine fully recognizes on its territory Article 25 of the Convention for the Protection of Human Rights and of the fundamental freedoms of 1950 to recognize the competence of the European Commission on Human Rights to accept from any person, non-governmental organization or group of persons a statement addressed to the Secretary General of the Council of Europe on the violation of the rights set out in the Convention by Ukraine and Article 46 of the Convention for the Protection of Human Rights and Fundamental Freedoms of 1950 for the recognition of compulsory and without special agreement the jurisdiction of the European Court of Human Rights in all matters concerning the interpretation and application of the Convention.

In order to resolve the question of the place of case law of the European Court of Human Rights in the national legal order in Ukraine, a separate law has been adopted - the Law of Ukraine "On Enforcement of Decisions and Application of the Practice of the European Court of Human Rights" of 26 February 2006. Article 2 of this Law stipulates that the Court's decisions are binding in accordance with Article 46 of the Convention. In Ukraine, a deliberate failure to comply with an official of a decision of the European Court of Human Rights is a crime and provides for criminal liability under Article 382 $\S 4$ of the Criminal Code of Ukraine.

Pursuant to Article 17 of the Law of Ukraine "On Enforcement of Decisions and Application of the Practice of the European Court of Human Rights", courts apply the Convention and the Court's case law as a source of law when considering cases. This legal prescription is a novelty in national law because it establishes that, in addition to the legal rules set out in the Convention itself, which national courts should use as a source 
of law in their cases, although this is rarely done so far, the provision that the decision of the Court in a particular case considered by the said Court is also a source of law for the Ukrainian law users.

In Europe, where a continental system of law exists in most states, the question of the application of the Court's decisions is resolved in such a way that its practice is a peculiar interpretation of the provisions of the legal norms of the Convention, facilitating its direct application. Thus, the Court's cases are not formally regarded as precedents, but are the only source of dynamic interpretation of the Convention. Tymchenko (2004), who notes that "the wording of Article 17 of the Law of Ukraine 'On Enforcement of Decisions and Application of the Practice of the European Court of Human Rights' on the use of the case-law of the Court as a 'source of law' is very incorrect, since it gives grounds to claim that the Court is making a law and that it is not true. It may have been more expedient to apply the formula: 'source of interpretation of law'”.

In support of this position, it should also be noted that, after the adoption of the Convention, the European Community has adopted, at various times since the entry into force of the Convention, a number of protocols thereto, including those which have supplemented its version with other rights not included therein. Such documents are, in particular, Protocol No. 1 to the Convention, Protocol No. 4 to the Convention and Protocol No. 7 to the Convention. This Protocols Convention was amended certain rights that are not included in it's, during its signing. If the European Community had conferred upon the Court normative powers, it would not have accepted, after the adoption and entry into force of the Convention, Protocols, which, in their wording, contained separate human rights not previously included in the Convention. However, it should be noted that it is not possible to apply the plain text of the Convention without taking into account the case law of the Court and vice versa. As Mahrelo (2013) points out, "the case law of the European Court of Human Rights, together with the body of the Convention, is a 'Convention right', flexible and constantly changing in nature".

In full agreement with the position on the need to understand the rulings of the European Court of Human Rights as a source of interpretation of law, let us return to its place in the tax law system. The Tax Code of Ukraine, in particular Article 3, which defines the tax law system, does not mention the decision of the European Court of Human Rights. But we should not forget that tax disputes fall into the category of administrative cases and in addition to substantive rules of the Tax Code of Ukraine are resolved on the basis of procedural rules of the Code of Administrative Justice of Ukraine by administrative courts. Therefore, it is precisely in the Code of Administrative Justice of Ukraine that the decision of the European Court of Human Rights was mentioned for the first time among all procedural laws of Ukraine. In particular, Article $8, \S 2$, of the Code states that the "court applies the principle of rule of law in the light of the case law of the European Court of Human Rights". However, it should be noted that such wording of the article is not entirely correct, since in fact, based on a literal interpretation of this article, the principle of rule of law equals the case law of the European Court of Human Rights by its legal nature and practical importance. Following the rules of legislative technique, it would also be advisable to replace parts 2 and 3 of this article, since part 3 refers to a guarantee of an 
appeal to an administrative court directly based on the Constitution of Ukraine. Because, despite the great importance of the case law of the European Court of Human Rights as a source of interpretation of law in Ukraine, it should be remembered that the Constitution of Ukraine is the Fundamental Law of Ukraine and has the highest legal force in Ukraine. Therefore, the legal positions of the European Court of Human Rights decisions contrary to the provisions of the Constitution of Ukraine cannot be accepted and applied in practice. The legislator's emphasis on the importance of applying the case law of the European Court of Human Rights in the administration of justice in administrative cases is quite right and well-considered, since the administrative courts in Ukraine were created to protect the rights and freedoms of the individuals and the citizens, the rights and legitimate interests of legal persons in their relations with public authorities. It is in the public-power sphere that they are mostly neglected and violated.

Summarizing the above, it should be noted that the Convention on the Protection of Human Rights and Fundamental Freedoms is the source of law, including tax law. For legal force, it is between the Constitution of Ukraine and laws of Ukraine. The decision of the European Court of Human Rights is the source of interpretation of the Convention. The decisions of the European Court of Human Rights are not possible without the proper prescriptions of the Convention and organically together with them form the so-called "law of the Convention". The latter has led to the definition of the case law of the European Court of Human Rights in the national legislation of Ukraine as a source of law.

\section{Problems arising from the application of the decisions of the European Court of Human Rights by Ukrainian courts in tax cases}

With the awareness of national authorities, including judges, of the importance of the European Court of Human Rights as a kind of Pan-European Constitutional Court, it begins to pay much more attention to the Convention and the practice of the European Court of Human Rights. As a result, a much greater willingness to apply the Convention directly is produced. Courts are obliged to apply the Convention in their activities, and judges to know it as well as the Constitution of Ukraine and other laws of the state, to navigate the judgment of the European Court of Human Rights and to consider them when considering a particular category of cases.

However, in the case of the Convention, the application of the general rules of interpretation must take into account its specificity, which is conditioned by the existence of the concept of "collective support" for the fulfilment of obligations. This implies, in particular, that all states equally adhere to the minimum European standard on issues related to the protection of human rights; this standard is self-evolving, driven by the desire to attain the absolute ideal reflected in the Preamble to the 1950 Convention, and that is why there is a need for a unified and progressive interpretation. Accordingly, the Convention must be applied uniformly in all States Parties, as interpreted by the European Court of Human Rights. It should be borne in mind that not only the decisions against Ukraine, but also the entire body of decisions of the European Court of Human Rights against other States Parties to the Convention. Otherwise, identified violations that have already been recognized in other States Parties may remain undermined when the Convention for the Protection of Human 
Rights and Fundamental Freedoms allows for the "early" correction of these violations. Such a mechanism makes it possible to fully realize Ukraine's obligations not only to the Council of Europe but also, above all, to its own citizens. As Judge of the European Court of Human Rights from Ukraine Yudkivska (2011) notes, "the decentralization of human rights protection, the distribution of the burden of such protection between the European Court of Human Rights and national courts is the only adequate response to the challenges that the European Court of Human Rights faces today, and a guarantee of an effective future court and of all human rights protection mechanisms".

Analysis of judicial practice of national courts of law shows that Ukrainian judges aware of the case law of the European Court of Human Rights. Although references to the case law of the European Court of Human Rights often remain general and concise, and they do not always refer to specific decision of the European Court of Human Rights indicating details, nevertheless, the case law of the European Court of Human Rights as a source of justification for the court's position is constantly growing. Yes, in almost every third case, in which opposite side were the tax authorities and which have been reviewed in the last five years was made reference to the case law of the European Court of Human Rights. However, an important and complex problem in the application of the case law of the European Court of Human Rights by Ukrainian courts is the proper procedures and legal bases. Onopenko (2011) emphasizes that "the mechanism of such application involves two ways: the first is the direct application of the case-law of the European Court of Human Rights, which is limited by the rules of the Convention and the decisions of the Court of Human Rights adopted in relation to Ukraine; second, the use of the legal positions of the European Court of Human Rights in the practice of the Ukrainian courts". In addition to these two methods, there is also a third so-called "reference" method, which merely mentions the existence of certain European standards on the subject matter of the dispute without specifying it, i.e. without reference to specific articles of the Convention and the decision of the European Court of Human Rights.

It is necessary to pay attention to the provisions of the resolution of Plenum of the Supreme Administrative Court of Ukraine "On decision in administrative case" dated May 20, 2013 No. 7, where it is stated that in the reasoning part of a decision rendered by an administrative court may also refer to a decision of the European Court of Human Rights. Courts should bear in mind that mere references in the motivating part to a provision of legislation without properly giving reasons for applying certain rules or not applying other rules relied on by a party in substantiating their claims cannot be considered as having adequate legal qualifications. That is, the courts must justify the appropriateness of reference to the decision of the European Court of Human Rights in each particular case. It follows therefore that the criteria for the expediency of such a reference should be determined, namely that the Convention and the decision of the European Court of Human Rights should be applied subject to the following conditions: where there are "legal" gaps in national law on human rights and fundamental freedoms as defined in the Convention and the Protocols thereto; to better understand those provisions of national law which have been amended or supplemented by decisions of the European Court of Human Rights; to 
put into practice such basic principles of the Convention as the rule of law, fairness, fair balance, just satisfaction, as these are quite new categories in Ukrainian law.

An example is the situation that arose in the first years of introduction of a transport tax in Ukraine ${ }^{3}$. Analysis of the Register of Judgments shows that in the courts of first instance taxpayers challenged the notification-decision on the accrued transport tax in approximately $40 \%$ of cases, and in the courts of appeal about 50-60\% of such claims were subject to satisfaction. The legislator laid the grounds for such a number of appeals. First, the legislator, trying to reduce the number of taxes and fees and not including it as an independent element in the list of local taxes and fees, defined by Article 10 of the Tax Code of Ukraine, cast doubt on the legality of its collection. Secondly, the introduction of a transport tax did not comply with the procedure established by the same Code for the adoption and entry into force of decisions on the introduction of local taxes and fees by local councils ${ }^{4}$.

The Supreme Court of Ukraine, considering the case on the legality and validity of the calculation of the transport tax in its decision of 18.01.2018 in the case K/9901/1648/17, No. 804/1241/17 applied the decision of the European Court of Human Rights in Serkov v. Ukraine, 07.07.2011, appl. No. 39766/05 and Shchokin v. Ukraine, 14.10.2010, appl. No. 23759/03 and 37943/06. These decisions found a violation of Article 1 of Protocol No. 1 to the Convention, since public authorities preferred the least favourable interpretation of national law, which led to the imposition of additional tax obligations on the applicant. Taking into account the case law of the European Court of Human Rights, which was formed on the basis of the imperative nature of the rule on the decision in favour of the taxpayer in the event of ambiguity in the interpretation of the rights and/ or responsibilities of such a payer, as well as the role of decisions of the European Court of Human Rights as a source of law in Ukraine, a panel of judges of the Supreme Court of Ukraine concluded that the definition to the owner of the vehicle tax liability for transport tax for 2015 is unlawful.

The above example regarding the particularities of the application of the provisions of the Convention and the case law of the European Court of Human Rights is not all-inclusive and comprehensive. However, the application of the case-law of the European Court of Human Rights by the Ukrainian courts indicates that the courts are able to provide fair judicial protection aimed at: balancing human rights and freedoms on the one hand and understanding and respect for these rights by the state on the other; the exercise of justice at such a level as to guarantee to every person, in the determination of his civil rights and obligations, the right to a fair trial; the support of the substantial legal potential of the provisions of the Convention and the decisions of the European Court of Human Rights. At the same time, the analysis of the case-law shows that there are a considerable number of cases of ambiguous interpretation of the same decisions of the European Court of Human Rights by the national courts of Ukraine. It is interesting that different interpretations of the same legal positions of the European Court of Human Rights are found in the decisions of the same national courts of Ukraine. Thus, in the Resolution No. 21-42a10 of January

\footnotetext{
3 Babin (2016).

${ }^{4}$ Babin (2018).
} 
31, 2011 in the case of the claim of VIK Firm LLC to the State Tax Inspectorate in Kherson on invalidation of tax notification-decisions, the Supreme Court of Ukraine has come to the conclusion that "in case a counterparty fails to fulfill its obligations to pay tax to the budget, liability and negative consequences are incurred for that person. This circumstance is not a ground for depriving a VAT payer of the right to his reimbursement if the payer has fulfilled all the conditions stipulated by law for obtaining such reimbursement and has the necessary documentary evidence of the amount of his tax credit". In its decision, the Supreme Court of Ukraine also stated that such a conclusion was "consistent with the case law of the European Court of Human Rights. Thus, in the case of Bulves AD v. Bulgaria, 22.01.2009, appl. No. 3991/03 the European Court of Human Rights stated that a taxpayer should not bear the consequences of a supplier failing to fulfill his obligations to pay the tax, as a result, pay value added tax a second time, and pay a fine. In the Court's view, such claims have become an undue burden for the taxpayer, who has distorted the fair balance that must be maintained between the public interest requirements and the protection of property rights".

However, in the resolution of June 14, 2016 in case No 826/14268/14 on the claim of FarforFaience LLC to the STI in the Shevchenkivsky district of the State Tax Service of Ukraine in Kyiv on the recognition of illegal and annulment of tax notification-decisions, the Supreme Court of Ukraine has substantially changed its legal position in cases concerning the confirmation of a tax credit for transactions with counterparties with fictitious features. As stated by the Supreme Court of Ukraine, "the primary documents which formed the basis for the formation of the tax credit and expenses taken into account in the calculation of the object of taxation, issued by the counterparty whose activity had signs of fictitious entrepreneurship, and signed on behalf of the person who denied his participation in their activities, cannot be considered properly prepared and signed by the authorized persons of the accounting documents certifying the fact of purchase of goods, works or services, and therefore the attribution of the amounts shown in them to tax credit and expenses are groundless". On such contradiction and inconsistency practice of the Supreme Court of Ukraine to case law of the European Court of Human Rights, was even drawn to the attention of one of the judges who considered the case $\mathrm{s}^{5}$.

The reasons for this situation can be conditionally divided into objective and subjective. Objective reasons are related to ensuring the most adequate translation into Ukrainian the provisions of the European Convention and the substantive nuances of the decisions of the European Court of Human Rights, especially as regards the reproduction of conceptual categories inherent in the diversity of the legal systems of the member states of the Council of Europe. Subjective reasons are the internal will of Ukrainian judges to implement European human rights standards into domestic jurisprudence, and this requires an appropriate level of legal consciousness.

We will note that there is indeed a problem with the quality translation of the European Court of Human Rights decisions. Pursuant to Article 18 of the Law of Ukraine "On Enforcement of Decisions and Application of the Practice of the European Court of

\footnotetext{
${ }^{5} \operatorname{Sam} \sin (2016)$.
} 
Human Rights", "courts are required to use the official translation of a decision of the European Court of Human Rights published in the official publication or, in the absence of a translation, the original text". However, there is no information on the state providing the courts with official translations of European Court of Human Rights decisions. The Ministry of Justice is conducting the definition of the publication, which will translate and publish the full text of the decisions of the European Court of Human Rights, on a competitive basis. However, in fact the institution of the official translation of the Court's decisions is provided only for decisions against Ukraine. Official translations of decisions in cases against Ukraine are published in the Official Journal of Ukraine and published on the official website of the Ministry of Justice. At the same time, the Ministry of Justice does not provide any translation of the Court's decisions in cases against other states. In this regard, the courts must appeal to the original texts of the decisions of the European Court of Human Rights. The parties may be referred to translators if the parties, in substantiating their claims, refer to the decision of the European Court of Human Rights. In this case, the translation is certified by a notary or certified by a specialized translation company. But it is not always possible for judges to verify that this translation complies with the original text. In fact, such a practical trend solves the problems with the translation of decisions of the European Court of Human Rights in cases against other states, but to some extent, it is doubtful.

Another problem in interpreting the provisions of the Convention and the decisions of the European Court of Human Rights is the quality of references to them by domestic courts. Monitoring the court practice on tax disputes by administrative courts for the application by them legal positions of the Court, allow concluding that the quality of the references to the European Court of Human Rights decisions remains poor. There is not only a lack of validity in the way in which the references to the Court's legal positions are applied contained in its decisions, as well as their complete absence, along with the incorrect use of the legal positions themselves on the basis of the factual similarity of the "plot" of cases, without taking into account the whole set of legally significant circumstances. The source of the law for the Ukrainian courts is not the Court's decision itself, but only part of it - ratio decidendi, which contains a legal interpretation of the Convention. It is the inability of Ukrainian judges to distinguish among the Court's numerous decisions those relevant to its case law and containing "ratio decidendi", which concentrate the doctrinal approaches to interpreting Convention rights and freedoms developed by the Court are one of the key reasons for misapplication misuse of case law of the Court's on national level. While the higher courts apply European human rights standards in their acts, they do not seek to actively extend the application of those standards by lower courts. This impedes the process of unification of standards in the field of human rights and freedoms, and does not facilitate the orientation of the lower courts to the proper and correct use of the legal position of the Court in the administration of justice, which ultimately hinders the attainment of the aims pursued by the ratification of the European Convention and recognition of the Court's jurisdiction. 


\section{Conclusion}

Summarizing the above, we can conclude about the importance role of the case law of the European Court of Human Rights in the administrative judicial process, in particular, in resolving public law disputes, the subject of that are public finances. Powerful systematic steps are beginning to be made in the direction of practical and effective inculcation of the Convention principles into national law and order on the side of the state, civil society and international organizations. The created normative-legal basis, which determines home courts' duty to use law alongside with the European Court on human rights practice and apply it, while interpreting the rights and freedoms principles. The analysis of national judgments shows the growing number of cases that refer to the decisions of the European Court of Human Rights. References to the case law of the European Court of Human Rights include not only decisions of the Supreme Court of Ukraine but also appellate and local administrative courts.

At the same time, the carried out analysis of court practice on tax disputes is evidence of insufficient influence of the Court standards, superficial and "ritual" application of legal Court positions, concerning different human rights, prevailing absence of the references to developed by the Court principles and doctrinal approaches for the appreciation of the situation and promulgation of legal decree. At resolving tax disputes there are often cases of ambiguous application of the same decisions of the European Court of Human Rights by national courts of Ukraine. In particular, there are cases where the same decision of the European Court of Human Rights was used by the national courts of Ukraine to substantiate their decision in favour of both the taxpayer and the tax authority. It is particularly unfortunate that such a practice is characteristic of the Supreme Court of Ukraine, whereas it is for this body to formulate conceptual approaches and methods for the use of European standards by the courts, to develop recommendations on the correct and uniform application of them in the administration of justice of the rules of the Convention and the case law of the European Court of Human Rights. To remedy this situation, it is advisable to ensure that all decisions of the European Court of Human Rights are translated into Ukrainian, not just those concerning Ukraine, and the Supreme Court of Ukraine should clarify the practice of applying the decisions of the European Court of Human Rights to lower courts.

\section{References}

Babin, I. I. (2016). The modern system of local taxes and fees of Ukraine. Societas et Iurusprudentia, IV (3), 21-40.

Babin, I. I. (2018). Tax Law: Textbook. Kyiv: Kondor.

Code of Administrative Justice of Ukraine. BVR. 2005, No. 35-36, No. 37, item 446, as subsequently amended.

Constitution of Ukraine. BVR. 1996, No. 30, item 141, as subsequently amended. Criminal Code of Ukraine. BVR. 2001, No. 25-26, item 131, as subsequently amended. ECtHR. Bulves AD v. Bulgaria. App. No. 3991/03, January 22, 2009. Retrieved January 11, 2020, from http://hudoc.echr.coe.int. 
ECtHR. Burden v. The United Kingdom. App. No. 13378/05, April 29, 2008. Retrieved January 11, 2020, from http://hudoc.echr.coe.int.

ECtHR. Feldman v. Ukraine. App. No. 76556/01 and 38779/04, April 08, 2010. Retrieved January 11, 2020, from http://hudoc.echr.coe.int.

ECtHR. Ferrazzini v. Italy. App. No. 44759/98, July 12, 2001. Retrieved January 11, 2020 , from http://hudoc.echr.coe.int.

ECtHR. J. B. v. Switzerland. App. No. 31827/96, May 03, 2001. Retrieved January 11, 2020, from http://hudoc.echr.coe.int.

ECtHR. Janosevic v. Sweden. App. No. 34619/97, July 23, 2002. Retrieved January 11, 2020, from http://hudoc.echr.coe.int.

ECtHR. Jussila v. Finland. App. No. 73053/01, November 23, 2006. Retrieved January 11, 2020, from http://hudoc.echr.coe.int.

ECtHR. Kadri v. France. App. No. 41715/98, March 27, 2001. Retrieved January 11, 2020, from http://hudoc.echr.coe.int.

ECtHR. Kurt Nielsen v. Denmark. App. No. 33488/96, February 15, 2000. Retrieved January 11, 2020, from http://hudoc.echr.coe.int.

ECtHR. Matsyuk v. Ukraine. App. No. 1751/03, December 10, 2009. Retrieved January 11, 2020, from http://hudoc.echr.coe.int.

ECtHR. Merit v. Ukraine. App. No. 66561/01, March 30, 2004. Retrieved January 11, 2020, from http://hudoc.echr.coe.int.

ECtHR. Mooren v. Germany. App. No. 11364/03, Grand Chamber, July 09, 2009. Retrieved January 11, 2020, from http://hudoc.echr.coe.int.

ECtHR. Rakitin v. Ukraine. Appl. No. 7675/04, January 11, 2007. Retrieved January 11, 2020, from http://hudoc.echr.coe.int.

ECtHR. Serkov v. Ukraine. App. No. 39766/05, July 07, 2011. Retrieved January 11, 2020 , from http://hudoc.echr.coe.int.

ECtHR. Shchokin v. Ukraine. App. No. 23759/03 and 37943/06, October 14, 2010. Retrieved January 11, 2020, from http://hudoc.echr.coe.int.

ECtHR. Smirnov v. Ukraine. App. No. 1409/03, July 30, 2009. Retrieved January 11, 2020, from http://hudoc.echr.coe.int.

ECtHR. Sokor v. Ukraine. App. No. 49009/07, December 09, 2010. Retrieved January 11, 2020, from http://hudoc.echr.coe.int.

ECtHR. Terem LTD, Chechetkin and Olius v. Ukraine. App. No. 70297/01, October 18, 2005. Retrieved January 11, 2020, from http://hudoc.echr.coe.int.

ECtHR. Västberga Taxi Aktiebolag and Vulic v. Sweden. App. No. 36985/97, July 23, 2002. Retrieved January 11, 2020, from http://hudoc.echr.coe.int.

ECtHR. Vergelskiy v. Ukraine. App. No. 19312/06, March 12, 2009. Retrieved January 11, 2020, from http://hudoc.echr.coe.int.

ECtHR. Von Sydow v. Sweden. App. No. 11464/85, October 08, 1987. Retrieved January 11, 2020, from http://hudoc.echr.coe.int.

European Convention for the Protection of Human Rights and Fundamental Freedoms. (1950), as amended by Additional Protocols. Retrieved January 11, 2020, from http://hudoc.echr.coe.int. 
Law of Ukraine "On Enforcement of Decisions and Application of the Practice of the European Court of Human Rights". BVR. 2006, No. 30, item 260.

Law of Ukraine "On International Treaties". BVR. 2004, No. 50, item 540, as subsequently amended.

Law of Ukraine "On Ratification of the Convention for the Protection of Human Rights and Fundamental Freedoms of 1950, the First Protocol and Protocols No 2, 4, 7 and 11 to the Convention". BVR. 1997, No. 40, item 263.

Mahrelo, M. (2013). A non-binding precedent: some aspects of the substance of the European Court of Human Rights decisions in the legal system of continental law. Bulletin of the Academy of the Bar of Ukraine, 3, 61-67.

Mazur, M. V., Tahiiev, S. R., Benitskyi, A. S., Kostrytskyi, V. V. (2006). Interpretation and application of the Convention for the Protection of Human Rights and Fundamental Freedoms by the European Court of Human Rights and the Courts of Ukraine. Luhansk: RVV LDUVS.

Onopenko, V. V. (2011). The Mechanism for the Protection of Human Rights in Ukraine Needs Substantial Improvement (Presentation at the International Conference). Law of Ukraine, 7, 64-68.

Resolution of Plenum of the Supreme Administrative Court of Ukraine "On decision in administrative case". May 20, 2013, No. 7. Retrieved January 11, 2020, from http://zakon2.rada.gov.ua/laws/show/v0007760-13.

Resolution of the Supreme Court of Ukraine "On invalidation and cancellation of tax notification-decision and tax claim". January 18, 2018, No. K/9901/1648/17, No. 804/1241/17. Retrieved January 11, 2020, from http://reyestr.court.gov.ua/Review/71692929.

Resolution of the Supreme Court of Ukraine "On invalidation and cancellation of tax notification-decision". January 31, 2011, No. 826/14268/14. Retrieved January 11, 2020, from http://www.reyestr.court.gov.ua/Review/14222189.

Resolution of the Supreme Court of Ukraine "On invalidation and cancellation of tax notification-decision". June 14, 2016, No. 21-42a10. Retrieved January 11, 2020, from http://www.reyestr.court.gov.ua/Review/58789047.

Sadchikova, O. V. (2009). Decisions of the ECHR and their significance for the Russian law enforcement practice: abstract. diss. . . cand. legal sciences. Moskow: Mosk. gos. in-t mezhdunar. otnoshenij.

State Judicial Administration of Ukraine. (2016). Separate Opinion of Judge of the Trial Chamber in Administrative Matters of the Supreme Court of Ukraine Samsin I. L. regarding the resolution of the Supreme Court of Ukraine of June 14, 2016 in the case of the claim of LLC "Porcelain-Faience" to the STI in the Shevchenkivsky district of the State Tax Service of Ukraine in Kyiv on the recognition of illegal and annulment of tax notices-decisions of 14.06.2016, 21-42a10. Retrieved January 12, 2020, from http://www.reyestr.court.gov.ua/Review/58874624\#.

Tax Code of Ukraine. BVR. 2011, No. 13-14, No. 15-16, No. 17, item 112, as subsequently amended. 
Timchenko, L. D. (2004). International Law: Textbook, stereotyped (3rd ed). Kharkiv: Konsul; Nacz. un-t vnutr. del.

Vaško, A. (2019). Intelligence Information within Criminal Proceedings. DANUBE: Law, Economics and Social Issues Review, 10(3), 267-283.

Yudkivska, A.Iu. (2011). Some Issues in the Application of the Practice of the European Court of Human Rights in Ukraine. Law of Ukraine, 7, 74-79. 